\title{
IIIISGUCDERGI.ORG
}

"IȘ, GÜç̣" ENDÜSTRi iLIȘKiLERi VE INSAN KAYNAKLARI DERGISi

"IS, GUC" INDUSTRIAL RELATIONS AND HUMAN RESOURCES JOURNAL

\section{"Membership", Dependencies And Free Riding In Networks - A Case Study Of The European Metal Sector}

\author{
Patrik Nordin \\ Department of Industrial Sociology \\ Vienna University \\ patrik.nordin@univie.ac.at
}

Ekim/October 2009, Cilt/Vol: 11, Say1/Num: 6, Page: 73-92

ISSN: 1303-2860, DOI: 10.4026/1303-2860.2009.0133.x

Makalenin on-line kopyasına erişmek için:

http://www.isgucdergi.org/?p=makale\&id=407\&cilt=11\&sayi=6\&yil=2009

To reach the on-line copy of article:

http://www.isguc.org/?p=article\&id=407\&vol=11\&num=6\&year=2009

Makale İçin İletişim/Correspondence to:

Yazarların e-posta adresleri verilmiştir. Writers e-mail was given for contact. 
(C) 2000- 2009

"İşGüç̧" Endüstri İlişkileri ve İnsan Kaynakları Dergisi

"İşGüç" Industrial Relations and Human Resources Journal

Ekim/October 2009, Cilt/Vol: 11, Say1/Num: 6

ISSN: 1303-2860, DOI: 10.4026/1303-2860.2009.0133.x

Editör/Editor-in-Chief

Aşkın Keser (Kocaeli University)

Editör Yardımcıları/Co-Editors

K.Ahmet Sevimli (Uludağ University)

Gözde Yilmaz (Kocaeli University)

Uygulama/Design

Yusuf Budak (Kocaeli Universtiy)

\author{
Yayin Kurulu / Publishing Committee \\ Dr.Zerrin Firat (Uludăg University) \\ Doç.Dr.Aşkın Keser (Kocaeli University) \\ Prof.Dr.Ahmet Selamoğlu (Kocaeli University) \\ Yrd.Doç.Dr.Ahmet Sevimli (Uludağ University) \\ Yrd.Doç.Dr.Abdulkadir Şenkal (Kocaeli University) \\ Yrd.Doç.Dr.Gözde Yilmaz (Kocaeli University) \\ Dr.Memet Zencirkıran (Uludağ University)
}

Uluslararası Danışma Kurulu / International Advisory Board

Prof.Dr.Ronald Burke (York University-Kanada)

Assoc.Prof.Dr.Glenn Dawes (James Cook University-Avustralya)

Prof.Dr.Jan Dul (Erasmus University-Hollanda)

Prof.Dr.Alev Efendioğlu (University of San Francisco-ABD)

Prof.Dr.Adrian Furnham (University College London-İngiltere)

Prof.Dr.Alan Geare (University of Otago- Yeni Zellanda)

Prof.Dr. Ricky Griffin (TAMU-Texas AEM University-ABD)

Assoc. Prof. Dr. Diana Lipinskiene (Kaunos University-Litvanya)

Prof.Dr.George Manning (Northern Kentucky University-ABD)

Prof. Dr. William (L.) Murray (University of San Francisco-ABD)

Prof.Dr.Mustafa Özbilgin (University of East Anglia-UK)

Assoc. Prof. Owen Stanley (James Cook University-Avustralya)

Prof.Dr.Işık Urla Zeytinoğlu (McMaster University-Kanada)

Danışma Kurulu / National Advisory Board

Prof.Dr.Yusuf Alper (Uludağ University)

Prof.Dr.Veysel Bozkurt (Uludağ University)

Prof.Dr.Toker Dereli (Işık University)

Prof.Dr.Nihat Erdoğmuş (Kocaeli University)

Prof.Dr.Ahmet Makal (Ankara University)

Prof.Dr.Ahmet Selamoğlu (Kocaeli University)

Prof.Dr.Nadir Suğur (Anadolu University)

Prof.Dr.Nursel Telman (Maltepe University)

Prof.Dr.Cavide Uyargil (İstanbul University)

Prof.Dr.Engin Yildırım (Sakarya University)

Doç.Dr.Arzu Wasti (Sabancı University)

Dergide yayınlanan yazılardaki görüşler ve bu konudaki sorumluluk yazarlarma aittir.

Yayınlanan eserlerde yer alan tüm içerik kaynak gösterilmeden kullanılamaz.

All the opinions written in articles are under responsibilities of the outhors.

None of the contents published can't be used without being cited. 


\title{
"Membership", Dependencies And Free Riding In Networks - A Case Study Of The European Metal Sector
}

\author{
Patrik Nordin \\ Department of Industrial Sociology \\ Vienna University
}

\begin{abstract}
:
The aim of this paper is to highlight the complex nature of informal industry networks and their functions. These networks enable the actors to be better aware of situations in other countries and to coordinate their actions accordingly. The theoretical part of this paper deals with the resource dependency and free riding, both of which can emerge in networks. On the other hand the term membership, usually referring to formal networks, is not necessarily suitable for the analysis of informal or not yet existing ones, thus requiring a new way of defining these types of networks. Empirically this paper draws from a survey made to the all the member affiliations of the EMF, using network methods to analyze the dependencies and free riding. Membership comes into play when discussing free riding in a network and imbalance between the actors' roles and resource inputs.
\end{abstract}

Keywords:Metal Sector; Policy Networks; Membership and "Membership"; Dependencies; Free Riding 


\section{Introduction}

The increased global character of industrial production has also meant challenges for national trade unions. It is no longer possible to work only inside one's own countries. Also international contacts are needed to answer to the challenge posed by the globalization, in form of among others restructuring, labor and wage dumping. Therefore international and European trade union federations have become important platforms for gathering the national trade under a single umbrella, trying to decrease internal competition between the trade unions. On the European-level, organizing trade unions based on regional dimension has been seen as the most obvious way, since it has been thought that the actors coming from the same region share similar culture, background and challenges towards globalization. By emphasizing the regional aspect the goal has also been to decrease competition between countries for foreign direct investments (FDIs) among others.

Outside these formal regional structures also informal networks have been formed. Typical for these networks is that they function on ad hoc basis, meaning ever-changing and potentially overlapping membership. Because of this, it harder to keep track on these networks, as even the members are not necessarily always aware of their existence. Therefore these could also be called un-networks. By making these networks visible to their members, they become real, and can eventually change form to more formal ones.

The aim of this paper is to highlight the complex nature of informal industry networks and their functions. These networks enable the actors to be better aware of situations in other countries and to coordinate their actions accordingly. The theoretical part of this paper deals with the resource dependency and free riding, both of which can emerge in networks. On the other hand the term membership, usually referring to formal networks, is not necessarily suitable for the analysis of informal or not yet existing ones, thus requiring a new way of defining these types of networks. Empirically this paper draws from a survey made to the all the member affiliations of the EMF, using network methods to analyze the dependencies and free riding. Membership comes into play when discussing free riding in a network and imbalance between the actors' roles and resource inputs.

\section{Background}

Metalworking is one of the oldest industrial sectors in Europe as well as a key sector, due to among other things the large number of people it employs. It is made up mainly of export-driven large companies and multinationals and has overcome massive restructuring during the last decade and a half. With a long tradition of strong trade unions and advanced structures for joint decision-making as well as coordinated action it has been at the forefront of Europeanization.

The EMF is the second largest European industry federation after UNI-Europa, with over six million members from 71 affiliated trade unions in 33 countries. The role it plays as a model for European industry federations in industrial sectors at European level is similar to that played by national negotiators from the sector in many countries. The strategy of the EMF has always been to advocate a strengthening of social dialogue, which it sees as a major part of any European social policy. Since 1993 it has developed a strategy of coordinating national collective bargaining on pay, and later working time and training. Under the coordination system each trade union must attain a minimum wage increase corresponding to inflation and a balanced share of productivity gains. The initial objective of this strategy was launched by IG Metall, aiming to prevent wage and social dumping in the EU. The EMF coordinating activities have always been held up as an example; both for crossindustry strategies like the Doorn Group, and for most of the European industry federations which have began discussions on this subject. 
The European Metalworkers Federation's (EMF's) strategy is based on two pillars: joint-commitment to European guidelines and political determination of EMF minimum standards, which all affiliates are expected to oblige. While coordination of collectives bargaining at national level is regarded important in preventing mutual undercutting in collective bargaining, the political determination of European minimum standards is seen as an important instrument for a steady and gradual increase in pay and working conditions in the industry. The employers are well aware of the established power of French and German unions in the sector, where IG Metall, which for a long time was the largest trade union in the world, does not hesitate to bring its strength to bear during the negotiations. The employers fear the power of a "French IG Metall", which could combine these strong cultures. Secondly, EU policy measures EMF and particularly IG Metall, has a unique influence on European trade union strategy and policies. This is partially for historical reasons, since the creation of European Coal and Steel Community (ECSC) in 1951, meant that metalworking sector was seen as truly European, and thus made it possible for the industry federations in the metal sector to become more involved in European affairs (Freyssinet 1998, 20).

The EMF approach has emphasized the national federations' role in setting up coordination. This allows progress to be made outside the context of social dialogue, i.e. despite the absence of any representative from the employers, who have been totally against the idea of negotiating pay at this level. It has even been suggested that in the metalworking sector, the initial resistance from the employers stimulated this strategy, since according to Dufour \& Hege (1999, 109), coordination was taken up after it became clear that joint negotiations were impossible. Coordination began thus as a default principle, although the EMF added that it would preferably take place with the social partners on the other side of the table.
The purpose of this is two-fold: first, to develop fruitful coordination, which is useful in itself, as it enables the adoption of general principles on wages, working time and training; and secondly, in the longer term, to put pressure on national and European employer representatives (Dufresne 2006). This strategy does not seem to have been the direct cause of moves towards social dialogue in other areas. For the moment coordination of collective bargaining and social dialogue are two separate processes.

\section{Modes of Networks and Coordination}

During the last couple of decades the network approach has become a popular way of explaining interaction, coordination and decision-making between different actors (e.g. Borgatti \& Foster 2003; Davis \& Greve 1997; Gulati et al 2000; Walker et al 1997). The research on the flows of interorganizational knowledge through interlocks (e.g. Mizruchi 1996; Haunschild \& Beckman 1998) has raised issues like intraorganizational mechanisms of horizontal communication structures (Galbraith 1973), and importance of different information channels for different actors at the different stages of processes (Rogers \& Argawala-Rogers 1995).

There are three main levels of inter-organizational interaction, defining how deep and thorough forms the collective action takes (Table 1). At the most loose level is cooperation, which strives only to informal interaction where no binding decisions are made. These ad hoc networks (i.e. issue networks) function fluidly and the membership in them is potentially ever-changing. At the second level, coordination is defined as action, where the actors are expected to follow and to some degree implement the joint action plans. In order to get full benefit of this, there needs to be a long term commitment to the common cause. At the highest level is collaboration, which requires institutionalized structures to organize joint action (Vegso 1986). For this to succeed, formal institutional settings are required, to guide this pro- 
cess.

Collective action can be dysfunctional when wrong type of action is undertaken, or based on a misunderstanding of the nature of the collective effort, when the wrong resources and tools are provided. Collaboration is not automatically a better approach than coordination or cooperation, even though it gives stability to the network. On the other hand stability can also mean difficulties in adapting to the changing environment, thus making the network potentially more vulnerable. On the other hand, collaborative network requires better commitment from the parties, making it more respected in the eyes of outsiders than loose ad hoc networks. works would most likely fit into the cooperation model, since they do not possess shared resources yet at this point and are very flexible. This is however, bound to change once they have established themselves by morphing into networks.

\section{Resource Dependency}

In organizational social network literature two perspectives: resource dependence and transaction cost economics, have been prominent. In both the transaction cost and resource dependence literatures, for instance, the motivation and rationale for cooperative, inter-organizational integration of activities is at the organizational level, either for reasons of efficiency related to reduced tran-

Table 1

Three Levels of Networking: Cooperation, Coordination and Collaboration (freely interpreted from Hickey 1986; Vegso 1986).

\begin{tabular}{|l|l|l|}
\hline Cooperation & Coordination & Collaboration \\
\hline -Short term & -Longer term & - Long term \\
-Informal relations & -More formal relations & -More pervasive relations \\
-Ad hoc information sharing & -Constructed communication & -Institutional communication \\
-Separate resources & channels & -Shared access to resources \\
& & -Shared resources \\
\hline
\end{tabular}

One of the main problems is that the grounds for cooperation can sometimes be vague, as the trade unions are not necessarily sure what they want from it and with whom to cooperate. Also, because these networks are not institutionalized, identifying them is not always that simple. Therefore these structures can be called un-networks, where "membership" is defined as not being known to the members of them. Because these un-networks may not exist, although there would seem to be demand for them, the trade unions are not fully accomplishing their potential by using their scarce resources inefficiently. Based on Table 1 these net- saction costs (e.g. Williamson 1985) or to gain resources and power (Pfeffer \& Salancik 1978). Organizations make strategic choices to form or become part of a cooperative network of other organizations when they see the advantages to such an arrangement outweighing the costs of maintaining the relationship, including any potential loss of decision autonomy. This is especially true for the trade union movement, which in the globalized world is even more dependent on cooperation across the borders to efficiently represent the workers' interests.

The literature suggests that interdependency can take three forms. The first type of inter- 
dependence is horizontal interdependence between competitors. These are alliances between organizations that compete for the same resources (e.g. Astley \& Fombrun 1983; Oliver 1990), such as sub-sectoral national trade unions in countries where same companies are having their sites. In horizontal alliances, the organizations exchange or pool their resources toward some greater goal, such as in broader trans- or international issues like growth and employment strategies or issues of sustainable development the trade unions are facing. The second is a symbiotic interdependence or vertical alliance (Pfeffer \& Salancik 1978). These represent an alliance between an international trade union confederation and those national trade unions supplying it inputs or using its outputs e.g. use of European Works Councils coordinators as intermediaries between the company and the trade union. The third type of interdependence is reciprocal, where national trade unions exchange both inputs and outputs (Borys \& Jemison 1989; Oliver 1990) in international issues like using their right to be heard on EU-policies and legislation. In these kinds of alliances, the exchange of ideas takes place at the organs of European trade union confederations on a manner of mutual hearing. The first two forms of dependencies are outcome based, while reciprocal is behavior based interdependency. There is also another variation of reciprocal interdependency, which takes unofficial form. In these kinds of non-institutionalized alliances the roles are not defined as strictly as in the above mentioned example.

Interdependency is not necessarily about being symmetrical, i.e. having equal exchange of information, but can also be asymmetrical. In a symmetric interdependence all the actors have same amount of power and access to information. In any network, and particularly in a non-institutionalized one, this is however seldom the case, as the actors are themselves responsible for the developing contacts with others in the network. Asymmetry comes from a situation when one of only a few actors possesses more power then others and can exert its will over others.

\section{Defining Membership and "Membership"}

Also the definition of membership in these networks can be vague, as some networks are open in the sense that there are no formal membership requirements. Knowledge networks are often of this type. But most other types of networks have restricted membership (e.g. Rosenkopf 2007). The basis for membership in this case seems to fall broadly into two categories: Members have a particular institutional role in their country and serve as a kind of country representative in the network; and membership is based on similar ideology and/or profession. "Membership" on the other hand is the opposite of membership. It is by definition a membership in a network which does not exist. Therefore it is more about similarities between actors based on some chosen variables and characters.

One way of looking at membership is though the policy networks model by Rhodes, which employs the term policy community to mean a particularly tightly integrated and single-minded policy network (e.g. Rhodes 1997; Marsh 1998; Rhodes \& Marsh 1992). This differs from the traditional view of policy communities that refers to the broader universe of actors and potential actors who share a common identity or interest in a certain policy sector (Wright 1988). Simply put, the Rhodes model assumes that three key variables determine what type of policy network exists in a specific sector.

First, the relative stability of a network's membership: Do the same actors tend to dominate the joint action over time or is membership fluid and dependent on the specific policy issue under discussion? Second, the network's relative insularity: Is it a cabal which excludes outsiders or is it highly permeable by a variety of actors with different objectives? Finally, the strength of resource dependencies: Do network members depend heavily on each other for valued resources such as money, expertise and legitimacy or 
are most actors self-sufficient and thus relatively independent of one another? From these three aspects a continuum emerges with tightly integrated policy communities on one end, which are capable of single-minded collective action, and loosely affiliated issue networks on the other, which find it far more difficult to mobilize collectively. The internal structure of policy networks is usually considered an independent variable, in that the structure of a policy network will help determine policy outcomes. For example, policy communities have more capacity than issue networks to steer or control the policy agenda.

Recently there has been considerable research on the topics of power within social networks and the stability of networks. Stability is determined by the likelihood of members leaving one group for another due to dissatisfaction with the members of the original group. The first major question arising is, what characteristics are associated with stable networks? Some studies have shown that a balance of power within a social network is necessary for stability within the network (e.g. Jackson 2001). On the other hand, strong power networks, characterized by some members owning complete power at the expense of other members are usually unstable (e.g. Okada et al 1998). This contrast in power levels is likely to cause friction between members of the network, thus leading eventually to instability. This social friction is avoided in networks where each member shares a relatively equal amount of power.

\section{Free Riding}

Closely related to power is free riding. According to a general definition of free riding it is action, where "an actor is benefiting from group action without bearing proportional or appropriate share of the group's costs." (Hardin 1982). This can become eminent through three different types of action. Exclusion of benefits as primary focus refers to failure to contribute appropriate financial resources towards group action, and failing to fully reveal preferences for group benefits and over appropriating shared resources. Measuring individual contributions as primary focus refers to withholding effort or knowledge and failing to perform monitoring functions. The third type of action functions as an alternative for traditional of free riding in the sense that failure to take part in action improves or enhances group coordination i.e. repeated interaction, communication activities and participation in sanctioning activities.

Already Olson (1965) concluded that nonexcludable benefits create weak direct incentives for self interested members to act in the group's collective best interest, even in cases where they might share a common objective and gain from group action. In this case not only excluding of benefits but also subtracting them has significance for influencing an actor's behavior since this becomes apparent when considering adding more members to the group, when coordinating action at a platform created for information sharing, as is case with the EMF, with the most obvious examples being coordination on pay, working time and training. So far there has not been any sanction mechanism for those trade unions that do not provide data from their own country, since apart from the coordination on pay, this is still on more or less voluntary base. Another issue that can be raised is, what happens when there are overlaps among the trade unions' membership. Countries like Belgium, Finland and France have several trade unions in the metal sector and representing same workers, thus leading to potential for free riding for some of them.

There are two key conditions for allowing members to free ride within private collective action organizations. Exclusion based free riding as in inability to fully exclude benefits from those that do not collaborate and measurement based free riding where inability to accurately determine an actor's contributions towards group action becomes eminent.

There are three types of groups responsible for creation of collective action (Olson 1965 
\& Hardin 1982). The greatest likelihood for creating collective benefits emerge in privileged groups that contain at least one member receiving a large enough portion of total group benefits to be willing to bear all of the costs for providing them. These groups are often small because that makes it easier to coordinate, while at the same time giving greater benefits for each member and making it easier to monitor free riding. In Latent groups forming and sustaining provisions of collective benefit are difficult to do. Their members receive very little of the total group benefits, thus leading to low incentives for the members to contribute resources towards group activities. Since these groups tend to be large, they need a formal organization to coordinate activities. Intermediate groups contain members receiving a large enough portion of the total group benefit to be willing to bear all the provision costs, but still making it possible for members to identify if members alter their contributions. Also in these groups coordination is required to supply collective good.

\section{Research Questions and Hypotheses}

This paper aims to answer the following questions:

1) Are there any non-institutionalized networks among EMF members and how is "membership"defined in these?

Hypothesis: Non-institutionalized networks are based on similar preferences among the trade unions, but their existence is not ne- cessarily clear for the "members".

In order for these networks to fulfill their potential, they need to become real networks. This can mean loosely affiliated issue networks or more tight policy communities. The form of these alliances can be permanent (in form of official groupings), ad hoc (based on the issue), or something in between.

2) How does resource dependency emerge in these networks through cooperation, coordination and collaboration?

Hypothesis: Powerful national trade unions are more capable of surviving without collaboration than their smaller, less powerful counterparts, leading to emergence of one-sided dependency (small, less powerful being dependent on the large, more powerful).

Large trade unions are more inclined for cross-border coordination, since they are to gain the most from sustaining stabile institutions and their own power positions, whereas small trade unions can rely on the large ones to do this. Based on the definitions in Table 2, it is possible to combine resource dependency, institutional, and network perspectives to explore one important issue regarding collaboration among trade unions, i.e. what are the factors associated with the extent of formality of the collaborative activities among trade unions in metal sector in Europe? Whether the form of joint action is cooperation, coordination or collaboration (see Table 1) depends on institutional ramifications as well as mutual resource dependency.

Table 2

Four Dimensions of Resource Dependency

(Based on Alexander 1993 and de Bruijn \& ten Heuvelhof 1995).

\begin{tabular}{|l|l|l|l|}
\hline Pluraformity & $\begin{array}{l}\text { How integrated and } \\
\text { interdependent the } \\
\text { networks are? }\end{array}$ & Formality & $\begin{array}{l}\text { Formal networks are easier } \\
\text { to handle, but their mecha- } \\
\text { nical connections mean less } \\
\text { predictability }\end{array}$ \\
\hline Resource dependency & $\begin{array}{l}\text { How much do the } \\
\text { networks differ in } \\
\text { function and scope? }\end{array}$ & $\begin{array}{l}\text { Instruments } \\
\text { ons, und agreements as } \\
\text { method for functioning net- } \\
\text { work }\end{array}$ \\
\hline
\end{tabular}


3) Is there free riding among the EMF members and under which conditions does it take place?

Hypothesis: On one hand, tight, formal networks are better regulated, increasing the possibility to sanction for free riding. On the other hand, it is easier to gain from free riding in tight, formal networks because of their better potential for achieving results. On group level free riding takes place when there is high satisfaction on the way the group is working (e.g. Rokkan \& Buvik 2003; Wittek \& Van de Bunt 2003), since the affiliates do not want to waste their scarce resources on something they know is going to take place despite their own action.

Group size is not in itself a critical issue, since some very large groups can have members behaving like oligopolists. On the opposite ends is a large network whose members decide to act unanimously. Especially in cases where the agreement of every member is required, however small the actor is, it has power over the whole network.

\section{Reliability}

The general reliability of network data has been analyzed by Bernard et al (1984). Their main conclusion was that respondents are very poor at remembering distinct events of communication with others. Furthermore, when asked to evaluate the scope of communication, the reliability of answers was even worse. Still, later studies have shown that respondents are very good at remembering stable patterns of relations that occur frequently over a longer time (Freeman et al 1987). The data used in this paper comes from questions concerning stable relationships and communication, so the reliability of the answers should be on acceptable level. The easiest way to evaluate the reliability of a network data is to look at how many relations are confirmed by both parties. Because the collection of data for this paper is not fully finished yet, also one-way unconfirmed relationships have been included.

\section{Procedures}

For this study, a survey was made to all the affiliated national trade unions $(\mathrm{n}=71)$ to gather information on self-reported actual contacts. This analysis shows real alliances, which the national trade unions have formed to strengthen their leverage. Because the scope of the analysis consists of inter organizational contacts and sub-networks, every trade union was given only one copy of questionnaire to answer. Alongside this, also official and unofficial EMF documents from the committee work were used to get background information on the processes and opinion exchanges behind the decisions. Finally, some expert interviews have been conducted with the EMF staff and some selected trade unions.

\section{FINDINGS}

\section{Membership and "Membership"}

There are two types of ways a trade union can be member of a network. Membership refers to institutionalized form of organizing, where the members are actively participating in the network action, sharing information and taking part in decision-making. "Membership" on the other hand refers to similarities between trade unions in their policy preferences that are not always known by the actors. Therefore it is possible that through "membership" there would be a huge potential for the actors to be able to identify these invisible networks and make them visible, thus eventually turning them into institutionalized networks.

One way of searching for these networks is by using blockmodels. Blockmodeling is a matrix algebraic method for sorting network actors into jointly occupied, structurally equivalent positions. A blockmodel is the partition of a sociomatrix of g actors, in one or more relational networks, into two or more discrete subgroups or positions, called blocks. The term block refers to a square submatrix of structurally equivalent actors that have very similar, if not identical, relations with actors occupying the other blocks. Blockmodeling is therefore a data reduction technique that systematically searches for relational patterns in network data by regrou- 
ping actors and presenting condensed aggregate-level information. The outputs are permuted density and image matrices displaying the pattern of ties within and between the blocks for each type of relations (e.g. Knoke 2008). A blockmodel can be constructed a priori using theoretical principles, for example, by sorting the trade unions by regions. Another alternative is to look for empirical patterns in a relational dataset.

Table 3 shows the densities within and between the members of the EMF regional groups. Since these groups are institutionalized and in most cases have a formal structure, it makes sense that the within densities are higher than the between densities. This also helps to see, how functioning formal structures are and how this affects the densities.

"It is very difficult to cooperate with our regional group, as the other members are not providing data for common use. They are not showing interest to unite." (South East)

"In our regional group there are many countries with different interests, making it very hard to cooperate." (South East)

"As members of the formal Visegrád co- untries, we have traditionally close connections with each other. The members of the regional group (excluding Poland) work together in the so-called Wiener Memorandum group with the trade unions from Austria and Germany. We inform each other on the situation of collective bargaining in each country, like about results of the negotiations, situation on the labour market etc." (Eastern)

The results from between and within densities support the expert interviews with the EMF policy officers (EMF 2008) about the functioning of the regional networks. The Nordic region has traditionally been a core area of transnational collective bargaining coordination, relying on highly advanced institutional structures within Nordic IN, a bargaining cartel of trade unions, which structures are equivalent to the EMFs. This has made the coordination and cooperation easier, as it has meant mutual commitment to the common agenda. Other active groups are the Central and Benelux, although according the EMF (2008), the networks lead by IG Metall districts of North Rhine-Westphalia and Bavaria, which are overlapping these, are gaining more ground.

Table 3

Within and Between Densities of EMF Regional Groups Based on Membership (A Priori).

\begin{tabular}{|l|c|c|c|}
\hline Group & $\mathbf{n} / \mathbf{n}_{\mathbf{m a x}}$ & $\begin{array}{c}\text { Density } \\
\text { (within) }\end{array}$ & $\begin{array}{c}\text { Density } \\
\text { (between) }\end{array}$ \\
\hline Central (AUT, GER, SWI) & $2 / 4$ & 0.417 & 0.116 \\
Benelux (BEL, LUX, NED) & $7 / 10$ & 0.411 & 0.051 \\
South East (BIH, BUL, CRO, KOS, MKD, MNE, ROM, SER) & $5 / 12$ & 0.159 & 0.034 \\
Eastern (CZE, HUN, POL, SVK, SLO) & $3 / 6$ & 0.333 & 0.079 \\
Southern (CYP, GRE, ITA, MAL, TUR) & $3 / 7$ & 0.214 & 0.045 \\
Nordic (DEN, FIN, ICE, NOR, SWE) & $12 / 15$ & 0.462 & 0.029 \\
South West (FRA, POR, SPA) & $5 / 12$ & 0.136 & 0.072 \\
British (IRL, UK) & $3 / 5$ & 0.300 & 0.052 \\
\hline
\end{tabular}

Within density = density within the group members

Between density = density between the members of the other groups 
Alongside the institutionalized networks, there is also need to find the non-institutionalized. The traditional blockmodel analysis does not, however, help when trying to observe these, since it requires a priori knowledge of the amount of groups, and in the case of non-institutionalized networks, this kind of knowledge is not available. Therefore a model based on a posteriori knowledge is required. Because the most obvious ground for "membership" is preference similarity, this can be used combined with the self-reported connections to observe these kinds of groups. The trade unions were asked to rank from 1-9, which issues they regarded as most important. Preference similarity defines the top 3 of the trade unions' ranking that was then applied into similarity based blocks. By using a posteriori blockmodels, 17 different issue preference blocks, were found. The Table 4 shows that in most cases the issue preference similarities did not follow the division into regional groups, hence many blocks with a 0.000 density. Therefore it can be said that in this regard the trade unions are not yet fully aware of each others preferences, and thus not exploiting these possibilities to form non-institutionalized groups.

"There are numerous forms of bilateral cooperation, which are exceptionally good for different reasons, but which are not used enough. Here I am primarily referring to help offered by foreign trade unions to countries in transition. There are companies from those countries, which often do not comply with international conventions. " (Central)

"In many cases we deal with issues like how to implement a law, but there is too little unity in incorporating our demands. So, for example, as long as we among ourselves have disagreements regarding issues like minimum wage, we will witness transfer of capital, discrimination in employment etc." (South West)
Interestingly, the block 9 emerging based on this analysis consists of two very big and influential trade unions, namely the GER1 and the SWE2. Combined these two have almost 2 million members out of approximately 5,4 million total membership. The broadest of blocks, the number 1 , scored a relatively high density, despite having affiliates from five different regions. Also the Block 1, consisting of members from five different regions scored high, (0.286) compared to the regional between densities in the Table 3, implicating that the members of this group are also cooperating in real life. Apart from the shared preferences, there does not seem to be any other factor connecting all of these affiliates.

\section{Table 4}

\section{Densities of Non-Institutionalized Groups (A Posteriori).}

\begin{tabular}{|l|c|}
\hline Group & $\begin{array}{c}\text { Density } \\
\text { (within) }\end{array}$ \\
\hline $\begin{array}{l}\text { Block 1: BEL2, BEL4, DEN1, FIN3, } \\
\text { FRA5, NED2, SLO1, UK1 }\end{array}$ & 0.286 \\
\hline Block 2: BEL1, FIN5, FRA6, ITA3 & 0.000 \\
\hline $\begin{array}{l}\text { Block 3: CYP1, FIN1, FRA2, } \\
\text { HUN1 }\end{array}$ & 0.167 \\
\hline Block 4: BEL3, DEN2, FRA4 & 0.000 \\
\hline Block 5: BUL1, BUL2, ROM3 & 0.333 \\
\hline Block 6: CRO1, FIN4 & 0.000 \\
\hline $\begin{array}{l}\text { Block 7: CZE1, GRE1, NOR4, } \\
\text { SWI1 }\end{array}$ & 0.000 \\
\hline Block 8: FIN2, UK3 & 0.000 \\
\hline Block 9: GER1, SWE2 & 0.250 \\
\hline Block 10: KOS1 & N/A \\
\hline Block 11: LUX1 & N/A \\
\hline Block 12: NOR1 & N/A \\
\hline Block 13: NOR3 & N/A \\
\hline Block 14: POL1 & N/A \\
\hline Block 15: POR1 & N/A \\
\hline Block 16: SWE1 & N/A \\
\hline Block 17: UK2 & \\
\hline & \\
\hline
\end{tabular}




\section{Resource Dependency}

There is no single dominant method to measure resource dependency, since there are several different aspects of it. A distinction between one-sided and mutual resource dependency can be made, implicating the balance between the actors. In one-sided dependency an actor is on the receiving end of resources more often than on the providing end, hence making it more reliable on others to gain access to critical resources. Actors providing resources for the network are usually the ones with most of them. Examples from other sectors (e.g. Routledge et al 2006) show how some trade unions from the Northern Europe pay higher membership fees than necessary without requiring proportional amount of influence based on this.

Whether dependency is one-sided or mutual can be observed by calculating the difference between incoming and outgoing ties. If an actor has more ties coming in than going out, it is more likely to be dependent on the other actors in the network for information and resources. This vertical alliance between the provider and receiver indicates strong onesided dependency. Mutual dependency arises when there is no big difference between the amount of incoming and outgoing ties. Depending on the direction and balance of the ties, this can enlarge the network (if the incoming and outgoing ties are not overlapping) or make it a closed network (if incoming and outgoing ties overlap each other). Usually institutionalized are characterized by the latter, while non-institutionalized are more open to new entries.

A more indirect way is to look at the resource dependency at the network level. This can be done by calculating the correlation between the affiliation fees a trade union pays for the EMF and the position it has in the network (i.e. degree centrality). Since affiliation fees are based on membership on the trade unions, there are pressures for both under reporting and over reporting them. These are based on variations in the number of affiliate union members across countries reflecting the organizational cultures that prevail in each country. For example, countries such as Belgium and France have several overlapping trade unions affiliated to the EMF, while countries like Germany only have a single dominant one. However, the level of affiliate fees depends on the density of union membership which grants more or less voting power to each of its members: The powerful German IG Metall is by far the largest contributor to the EMF and has even created its own regional networks structure to function alongside the EMF mandated.

It is not rare for individual trade unions to declare more members than they have on their books and subsequently pay higher fees to the federation as a strategy to obtain more voting power, although conversely some may declare less to reduce their fee. Thus the relative status and power of each member varies tremendously and creates tensions as reflected by an official arguing that the payment of high affiliation fees does not entail that these particular unions will be more active: Apart from the above stated reasons, also lack of resources a trade union possesses can lie behind the decision to under report its membership. This holds true especially in the new EU member states in Eastern Europe, with weak traditions of independent trade unions and lack of work force. While a trade union might have large membership, it still does not guarantee that it can afford to employ enough officers to oversee their rights.

As can be seen from the Table 5, there are big differences between the trade unions' dependency rates based on the difference between incoming and outgoing ties. For example DEN1 which has the highest degree centrality also scores high on difference between incoming and outgoing ties (0.282), implicating its role as powerful actor that is actively participating in the cooperation processes. Another of the big ones, GER1 scores low (0.958) on difference between incoming and outgoing ties, but this can be explained by the power reputation of the GER1, as it seeks to take the leading role in Europe.

Benchmarking is a vital part of the resource 
Table 5

Measurements of Resource Dependency

\begin{tabular}{|c|c|c|c|c|c|c|c|}
\hline Affiliate & $\begin{array}{c}\text { Balance between } \\
\text { Incoming and out- } \\
\text { going ties }\end{array}$ & $\begin{array}{l}\text { Degree cen- } \\
\text { trality }\end{array}$ & \begin{tabular}{|c|}
$\begin{array}{c}\text { Affiliate fees } \\
\text { (eur) }\end{array}$ \\
\end{tabular} & Affiliate & $\begin{array}{l}\text { Balance between } \\
\text { incoming and out- } \\
\text { going ties }\end{array}$ & $\begin{array}{l}\text { Degree cen- } \\
\text { trality }\end{array}$ & $\begin{array}{c}\text { Affiliate fees } \\
\text { (eur) }\end{array}$ \\
\hline \begin{tabular}{|l|} 
NED1 \\
\end{tabular} & +14 (N/A) & 20.000 & 41600 & SPA3 & $+1(\mathrm{~N} / \mathrm{A})$ & 1.429 & 14040 \\
\hline SWE3 & $+12(\mathrm{~N} / \mathrm{A})$ & 17.143 & 62920 & SWI2 & $+1(\mathrm{~N} / \mathrm{A})$ & 1.429 & 8320 \\
\hline CZE1 & +11 (N/A) & 15.714 & 16724 & BEL5 & $0(0.000)$ & 8.571 & 5652 \\
\hline FRA3 & +11 (N/A) & 15.714 & 41600 & FRA2 & $0(0.000)$ & 2.857 & 5200 \\
\hline AUT1 & +10 (N/A) & 14.286 & 91000 & GRE1 & $0(0.000)$ & 7.143 & 6475 \\
\hline ITA1 & +10 (N/A) & 14.286 & 104000 & CYP1 & $-1(0.667)$ & 5.714 & 416 \\
\hline SPA2 & +10 (N/A) & 14.286 & 52000 & FIN5 & $-1(0.800)$ & 10.000 & 5200 \\
\hline SPA1 & +9 (N/A) & 12.857 & 52000 & GER1 & $-1(0.958)$ & 52.857 & 884000 \\
\hline FRA1 & $+8(\mathrm{~N} / \mathrm{A})$ & 11.429 & 39520 & NOR3 & $-1(0.875)$ & 12.857 & 8320 \\
\hline SVK1 & $+8(\mathrm{~N} / \mathrm{A})$ & 11.429 & 4494 & UK2 & $-1(0.800)$ & 11.429 & 13000 \\
\hline BIH1 & $+5(\mathrm{~N} / \mathrm{A})$ & 7.143 & 1040 & BEL2 & $-2(0.714)$ & 14.286 & 83200 \\
\hline FIN2 & $+5(2.250)$ & 12.857 & 11440 & FRA6 & $-2(0.600)$ & 11.429 & 6240 \\
\hline ITA2 & $+5(\mathrm{~N} / \mathrm{A})$ & 7.143 & 52000 & SWE2 & $-2(0.833)$ & 24.286 & 141771 \\
\hline MAL1 & $+5(\mathrm{~N} / \mathrm{A})$ & 2.857 & 1040 & SWI1 & $-2(0.500)$ & 7.143 & 29792 \\
\hline ROM1 & $+5(\mathrm{~N} / \mathrm{A})$ & 7.143 & 2080 & UK1 & $-2(0.867)$ & 32.857 & 219440 \\
\hline SER1 & $+5(\mathrm{~N} / \mathrm{A})$ & 7.143 & 3120 & DEN2 & $-3(0.769)$ & 21.429 & 8320 \\
\hline FIN4 & $+4(2.000)$ & 11.429 & 5200 & KOS1 & $-3(0.500)$ & 11.429 & 1040 \\
\hline FRA4 & $+4(5.000)$ & 8.571 & 5200 & NED2 & $-3(0.571)$ & 12.857 & 5200 \\
\hline NED3 & $+4(\mathrm{~N} / \mathrm{A})$ & 5.714 & 11700 & ROM3 & $-3(0.400)$ & 10.000 & 1144 \\
\hline POL1 & $+4(2.000)$ & 15.714 & 6240 & UK3 & $-3(0.250)$ & 5.714 & 10400 \\
\hline ROM2 & $+4(\mathrm{~N} / \mathrm{A})$ & 5.714 & 1040 & BEL3 & $-4(0.692)$ & 25.714 & 41600 \\
\hline TUR1 & $+4(\mathrm{~N} / \mathrm{A})$ & 5.714 & 1123 & BEL4 & $-4(0.765)$ & 32.857 & 10400 \\
\hline UK4 & $+4(\mathrm{~N} / \mathrm{A})$ & 5.714 & 41600 & CRO1 & $-4(0.600)$ & 20.000 & 2260 \\
\hline BUL3 & $+3(\mathrm{~N} / \mathrm{A})$ & 4.286 & 520 & HUN1 & $-5(0.545)$ & 20.000 & 3099 \\
\hline FRA7 & $+3(\mathrm{~N} / \mathrm{A})$ & 4.286 & 6240 & BEL1 & $-6(0.667)$ & 31.429 & 47320 \\
\hline ICE1 & $+3(\mathrm{~N} / \mathrm{A})$ & 4.286 & 5200 & BUL2 & $-6(0.143)$ & 10.000 & 520 \\
\hline POL2 & $+3(\mathrm{~N} / \mathrm{A})$ & 4.286 & 1040 & NOR1 & $-6(0.625)$ & 24.286 & 24284 \\
\hline POR2 & $+3(\mathrm{~N} / \mathrm{A})$ & 4.286 & 26260 & FIN1 & $-7(0.611)$ & 27.143 & 65000 \\
\hline SWE1 & $+3(1.375)$ & 17.143 & 11960 & BUL1 & $-9(0.308)$ & 20.000 & 1040 \\
\hline FIN3 & $+2(1.333)$ & 12.857 & 5980 & SLO1 & $-13(0.278)$ & 27.143 & 3737 \\
\hline MKD1 & $+2(\mathrm{~N} / \mathrm{A})$ & 7.143 & 1766 & ITA3 & $-14(0.067)$ & 22.857 & 39000 \\
\hline MNE1 & $+2(\mathrm{~N} / \mathrm{A})$ & 2.857 & 1144 & LUX1 & $-15(0.118)$ & 24.286 & 10400 \\
\hline NOR2 & $+2(\mathrm{~N} / \mathrm{A})$ & 2.857 & 5200 & FRA5 & $-18(0.357)$ & 48.571 & 35360 \\
\hline IRL1 & $+1(\mathrm{~N} / \mathrm{A})$ & 1.429 & 5200 & POR1 & $-23(0.179)$ & 40.000 & 15600 \\
\hline NED4 & $+1(\mathrm{~N} / \mathrm{A})$ & 1.429 & 5200 & DEN1 & $-28(0.282)$ & 57.143 & 88400 \\
\hline NOR4 & $+1(1.250)$ & 8.571 & 7800 & & & & \\
\hline
\end{tabular}

Normal affiliate fee is 0,52 eur/member. For countries in Eastern and Central Europe the fee is $1 / 5$ of this $(0,104$ eur). Source: EMF personal notification (2009).

- Network centralization $43.98 \%$

- Correlation between membership fee \& degree centrality $=0.497$

dependency, as can be witnessed by the example of IG Metall. In January 2000, they as pattern setters started its bargaining round by demanding a considerable increase of $5,5 \%$, justifying its claims on the grounds that inflation rate, productivity growth and redistribution component together were estimated to increase this much. Hence the IG Metall's claims were in line with the EMF benchmark. However, later in 2000, new wage agreements were concluded, first in the chemical and then in the metalworking sector, clearly conflicting with the EMF and Doorn benchmarks (Schulten 2000).

The North-Rhine Westphalia branch of IG Metall was one of the first trade unions in to establish cross-border links with neighbo- 
ring Belgium and the Netherlands (Gollbach 2000) and introducing a benchmark system to coordinate collective bargaining. Although the German trade unions took initiative to form these networks, they were criticized by several other countries for being too moderate in their demands. On the other hand, the dependency on German pattern-setters has usually been relatively low in countries like France, given their marginal role and lack of enthusiasm for subscribing these benchmarks (Dufour \& Hege 1999). Nevertheless the French average real-wage growth came closer than the German one to the EMF target. The French trade unions had been associated at an early stage with both the Doorn initiative and the EMF discussions on wage coordination, but they had chosen to remain at the margin on both of these processes (Erne 2008, 104). This could also be seen from the relatively low degree centralities of the French trade unions (average 14.694) compared to other big countries.

\section{Free Riding}

Before starting to measure free riding, several aspects need to be taken into consideration. First, should the input (resources) or output (incentives) of free riding be measured? Second, should free riding activity or actors' degree of free riding be measured? Measuring free riding in large groups is difficult and complex due to a combination of factors; the broad definition given to the concept of free riding, the wide range of activities that have been used to describe free riding, and the latent nature of most free riding actions. Therefore developing an accurate measure for free riding is challenging. Since there is no broadly accepted measure for free riding (Olson \& Cook 2008), it is also a challenge to test empirically the effectiveness of alternative research strategies proposed to mitigate the free riding problem, especially the effectiveness of alternative selective incentives.

A general understanding of a meaning of free riding implies that an actor receives more incentives in proportion to the total amount than could be assumed based on the resources it has shared with the others in a network. In other words, this actor-level free riding is distinction between input and output. This model also takes into consideration the power relations between the actors, since influence over access to shared resources is at the forefront here. Still, free riding in this sense does not necessarily imply mutual resource dependency, because of its resource imbalances.

On the other hand, free riding can also be measured on the network level. Here a factor analysis on dominant free riding activities comes into play. Exploratory factor analysis uses variability among observed variables in terms of fewer unobserved variables called factors in determining whether the observed variables are modeled as linear combinations of the factors, plus "error" terms. Closely related to this is principal component analysis, where transformation of a number of possibly correlated variables into a smaller number of uncorrelated variables called principal components is done so that the first principal component accounts for as much of the variability in the data as possible, and each succeeding component accounts for as much of the remaining variability as possible. One disadvantage of the principal component method is that it does not provide a test for lack-of-fit, making it thus possible only to examine the results and determine if they are small or close to zero.

\section{Table 6}

\section{Factor Analysis (Free Riding): Principal Component Method}

\begin{tabular}{|l|c|c|c|}
\hline Variable & Factor 1 & Factor 2 & Factor 3 \\
\hline V5 & 0.972 & 0.018 & 0.024 \\
V4 & 0.961 & -0.040 & -0.050 \\
V3 & 0.931 & 0.235 & -0.038 \\
V6 & 0.555 & -0.021 & 0.484 \\
V1 & 0.030 & 0.819 & -0.327 \\
V2 & 0.090 & 0.797 & -0.066 \\
V7 & -0.107 & -0.127 & 0.899 \\
\hline Eigenvalue & 3.064 & 1.525 & 1.158 \\
Explanatory proportion & 0.438 & 0.218 & 0.165 \\
\hline
\end{tabular}

Factors 1-3 explaining $82.1 \%$ of variance 
The communalities for the ith variable are computed by taking the sum of the squared loadings for that variable.

Table 7

\section{Communalities (Free Riding)}

$$
\widehat{h}_{i}=\sum_{j-1}^{m} \hat{l}_{i j}^{2}
$$

\begin{tabular}{|l|c|}
\hline Variable & Communality \\
\hline V5 & 0.779 \\
V4 & 0.817 \\
V3 & 0.648 \\
V6 & 0.923 \\
V1 & 0.945 \\
V2 & 0.542 \\
V7 & 0.836 \\
\hline
\end{tabular}

\section{They}

7 indicator variables:

V1) Trade union influence / leverage

V2) Participation in group work

V3) Functioning of group

V4) Success of group

V5) Cooperation among trade unions

V6) Competition between trade unions

V7) Power Reputation

Factor 1: strong loadings V3 - V6 à "outer conditions"

Factor 2: strong loadings V1 - V2 à "member free riding"

Factor 3: strong loading V7 (V6 threshold value)

The three factors were constructed from seven different indicator variables, measuring both the affiliate activity and satisfaction. This enables understanding what might lie behind free riding. Factor 1, named here "outer conditions" refers to network level of aspects, namely how much potential the network has of accomplishing its targets. Factor 2, "member free riding" concentrates more on an actor level and how much say and willingness an affiliate has on cooperation. It is worth to note that influence and leverage an affiliate has over the processes is likely to correlate with the level of participation. Therefore free riding emerges in cases where the there is little correlation. In the
Factor 3, only actors' power reputation got strong loading, indicating that powerful national trade unions are likely to survive without cooperation, since they are more responsible for the output side on the networks than the input, thus making them less dependent on the others.

Free riding creates problems for collective action networks because the members are able to withhold key resources necessarily to produce and supply benefits for the network. Key resources may include those needed to produce benefits, those needed to coordinate activities, and resources needed to sustain a formal organization. The free rider problem is commonly associated with the challenges confronting collective action, but it can also be recognized as a challenge facing team production, where the value of team output is shared among its members and it is difficult to determine the marginal input of each affiliate. Many collective action organizations, like the EMF confront both of these difficulties. They attempt to supply member benefits which are difficult to exclude and where identifying contributors can be challenging. As an example is coordination rule of collective bargaining that requires one of the national affiliates to act as pattern-setter, thus requiring someone to share their own resources without knowing whether the others are also going to do the same. This leads to the question pattern-takers. As a general rule, for pattern bargaining to be effective a critical mass of pattern-taking units is required for macrolevel coordination to succeed (Traxler et al 2008). In Europe Germany is quite natural pattern-setter, because of its size and strong trade unions. The big question, however, is whether German trade unions are ready to take that role and to what extent affiliates in other countries are considering bargaining outcomes achieved by the pattern-setters.

Coordination is based on joint effort, thus there exists a possibility of exposing oneself to the problem of team production (e.g. Alchian \& Demsetz 1972). As long as the performance of the network depends on the joint effort or result of the behavior of all the 
members of the network, the ability to observe the individual behavior of each member becomes a critical issue. According to studies of group behavior (Olson 1965; Albanese \& Van Fleet 1985), increased group size will make it more difficult for the network administration to relate the contribution of each single member to the collective performance of the group. This issue concerns the problem of verification of behavior and is can potentially be substantial in a network where the division of resources among members is unequal.

\section{CONCLUSIONS}

This paper focused on contacts between national trade unions in the European metal sector by using network approach. By looking only at the official committee interlocks, we get a picture of "posting lists", i.e. to whom the official information is available. These networks are institutionalized and tell little about the preference similarities or power positions of the members. Therefore unofficial non-institutionalized un-networks were studied, trying to identify differences between membership and "membership". Especially in bigger projects like European Integration, free riding is a potential problem. Some trade unions are lacking resources to participate in joint action, while others might simply not be interested in it. The coordination rule implemented by the EMF has helped to overcome a potential free riding problem by binding the national trade unions to a common cause. Still, there are factors that affect this. In this paper we have identified some of these factors, by using factor analysis. On the other hand free riding can be seen as a challenge facing trade unions trying to build cross-national cooperation to counterbalance issues like labour and wage dumping or restructuring. This might eventually lead to decreased power position for the labour, as they can not concentrate their resources behind a common cause.

In this paper we have studied free riding on two different levels: On actor level and network level. The former gives implications to whether an actor is on the receiving or dis- tributing end of resources meant to be shared by the network. This was done by looking at the difference between input and output. On the network level, free riding was measured as tendency, where through factor analysis the dominant free riding activities were identified. The lack of a single dominant indicator suggests that free riding is more complex than might be thought. Strongest indicators found were influence or leverage a trade union possesses over the network, and competition between trade unions. This indicates what was already suggested in the second hypothesis, namely that powerful national trade unions are more capable and inclined to survive without collaboration, leading to one-sided dependency.

The results showed that the trade unions are not aware of potential for non-institutionalized networks. These networks, if existing, are characterized by their ad hoc form, meaning that the membership can vary from issue to issue. Apart from the regional similarities between actors, which are stated in the EMF statues, the "membership" based issue networks showed us, around which issues there is a possibility for cooperation. This does not necessarily mean that trade unions with similar preferences would cooperate in real life, because there are also other factors which can in some cases be more important when deciding on cooperation. This kind of information however helps the trade unions to find new partners to cooperate with. By combining data from the self-reported cooperation network and issue network, overlaps emerge, enabling us to analyze more broadly grounds for cooperation.

Often the failure of trade unions from different countries to cooperate has been explained by national differences. This paper has tried to move beyond that explanation by putting emphasis on a posteriori cooperation, meaning groups that are based on something else than what the institutional ramifications might suggest. Network integration can be measured by both actor and network (block) level density, which show how well the trade unions connected to each 
other. This enabled us to analyze the scale and scope of cooperation between the actors, based on the connections they have. Resource dependency theory suggests that organizations can not survive alone. Instead they must constantly interact with their environments. According to the theory, organizations seek to gain control over their environment through alliances. These alliances can insulate an organization from its external environment and lessen the effects of environmental uncertainty (Pfeffer \& Salancik 1978; Galaskiewicz 1985; Miner et al. 1990). Once an organization becomes dependent on another organization, it can no longer make decisions in a vacuum but must consider the other organizations' possible actions when making decisions (Pfeffer \& Salancik 1978). This is one of the main results from the EMF coordination approach, which emphasizes joint commitment and political determination.

Resource dependency is usually seen as binding actors to a common cause. However, trouble may arise, if the dependency is not mutual. Imbalances between the levels of dependence among trade unions are likely to result of free riding, which can be intentional or unintentional. The literature on imbalances between trade unions from the new EU countries and the EU15 (e.g. Leonard et al 2006), argue that there is different relevance and feasibility of sectoral level in new and old EU countries. Since the most critical cross-country issue is collective bargaining and social dialogue, weaknesses in these are affecting seriously the balance between the affiliates.

\section{REFERENCES}

Albanese, Robert \& Van Fleet, David. The Free Riding Tendency in Organizations. Scandinavian Journal of Management Studies. 2(1985):2, pp. 121-136.

Alchian, Armen. \& Demsetz, Harold. Production, Information Costs, and Economic Organization. American Economic Review 62(1972):N/A pp. 777-795.

Alexander, Ernest R. Interorganizational Coordination: Theory and Practice. Journal of Planning Literature 7(1993):4, pp. 328-343.

Astley, Graham W. \& Fombrun, Charles J. Collective Strategy: Social Ecology of Organizational Environments. Academy of Management Review 8(1983):4, pp. 576-587.

Bernard, Russell; Killworth, Peter; Kronenfeld, David \& Sailer, Lee. On the Validity of Retrospective Data: The Problem of Informant Accuracy. Annual Review of Anthropology 13(1984), pp. 495-517.

Borgatti, Steve \& Foster, Pacey. The Network Paradigm in Organizational Research: A Review and Typology. Journal of Management 29(2003):6, pp. 991-1013.

Borys, Byran. \& Jemison, David B. Hybrid arrangements as strategic alliances: Theoretical issues in organizational combinations. Academy of Management Review 14(1989):2, pp. 234-249.

Busemeyer, Marius R; Kellermann, Christian; Petring, Alexander \& Stuchlík, Andrej. Overstretching Solidarity? Trade Unions' National Perspectives on the European Economic and Social Model. Friedrich-Eberhart Stiftung International Policy Analysis, September 2007.

De Bruijn, Hans \& ten Heuvelhof, Ernst. Policy Networks and Governance. In Weimer, David L (ed.). Institutional Design. Dortrecht: Kluwer 1995. 
DiMaggio, Paul J. \& Powell, Walter W. The Iron Cage Revisited: Institutional Isomorphism and Collective Rationality in Organizational Fields. American Sociological Review 48(1983): 2, 147-160.

Dufour, Christian \& Hege, Adelheid. Quelle coordination syndicale des négociations en Europe? Chronique Internationale de l'IRES , No.60, pp.108-117

Erne, Roland. European Unions - Labor's Quest for a Transnational Democracy. Ithaca: Cornell University Press 2008.

European Metalworkers' Federation. The EMF Structure and Areas of Work. EMF EU Policy Seminar for Full-Time Union Officers, Bad Hofgastein 2008.

Freeman, Linton, Romney, Kimball \& Freeman, Sue. Cognitive Structure and Informant Accuracy. American Anthropologist 89(1987):2, pp. 311-325.

Freyssinet, Jacques. Dialogue Social et Construction Européen. Chronique Internationale de l'IRES, les acteurs sociaux nationaux face a la Construction Européene. October 1998, pp. 5-23.

Galbright, Jay R. Designing Complex Organizations. Reading: Addison-Wesley 1973.

Gollbach, Jochen. Grenzüberschreitende Koordinierung als Weg zu einer solidarischen europäischen Gewerkschaftspolitik? Das Beispiel der Tarifpartnerschaft Belgien-Niederlande-Nordrhein-Westfalen von Gewerkschaften der Metallbranche, $\mathrm{PhD}$ Dissertation. Oldenburg: Universität Oldenburg 2000.

Gulati, Ranjay; Nohria, Nitin \& Zaheer, Akbar. Strategic Networks. Strategic Management Journal 21(2000):3, pp. 203-215.
Hardin, Russell. Collective Action. Johns Hopkins University Press for Resources for the Future, Baltimore 1982.

Haunschild, Pamela R. \& Beckman, Christine M. When Do Interlocks Matter? Alternate Sources of Information and Interlock Influence. Administration Science Quarterly 43(1998):4, pp. 815-844.

Hickey, Delina. Collaboration, Cooperation and Coordination. Toward a Definition for Educators and Job Trainers.

http:/ /www.eric.ed.gov/ERICDocs/data/e ricd ocs 2 s q 1 / con tent_s to rage_01/0000019b/80/2f/32/66.pdf

Jackson, Matthew O. The Stability and Efficiency of Economic and Social Networks. In Sertel, Murat \& Koray, Semih (eds.). Advances in Economic Design. Springer-Verlag, Heidelberg 2003.

Knoke, David \& Yang, Song. Social Network Analysis - Second Edition. Sage, London 2008.

Lallement, Michel. Relations Professionelles et Emploi: Du Niveau a la Configuration. Sociologie du Travail 2(1998), pp. 209-231.

Leonard, Evelyne ; Rochet, Delphine \& Vandenbussche, Isabelle. The Challenges of Enlargement. in Dufresne, Anne; Degryse, Christophe \& Pochet, Philippe (eds.). The European Sectoral Social Dialogue - Actors, Developments and Challenges. P.I.E. Peter Lang, Brussels 2006 pp. 305-334.

Marsh, David (ed.). Comparing Policy Networks. Open University Press: Buckingham

Oliver, Christine. Determinants of Interorganizational Relationships: Integration and Future Directions. Academy of Management Review 15(1990):2, pp. 241265. 
Olson, Mancur. The Logic of Collective Action. Public Good and the Theory of Groups. Harvard University Press, Cambridge 1965.

Olson, Frayne \& Cook, Michael L. Towards a Measurement of Free Riding within Private Collective Action Organizations. Paper presented at American Agricultural Economics Association Annual Meeting in Orlando 2008.

Pfeffer, Jeffrey \& Salancik, Gerald. The External Control of Organizations. A Resource Dependency Perspective. Harper and Row, New York 1978.

Rhodes, Rod A.W. \& Marsh, David. New Directions in the Study of Policy Networks. European Journal of Political Research 21(1992):1-2, pp. 181-205.

Rhodes, Rod A.W. Policy Networks: A British Perspective. Journal of Theoretical Politics 2(1997):2, pp. 293-317.

Rogers, Everett \& Argawala-Rogers, Rekha. Communication Networks in Organizations. in Corman, Steven R; Banks, Stephen P; Bantz, Charles R \& Mayer, Michael E (eds.). Foundations of Organizational Communication: A Reader. Longman, White Plains. pp. 333-348.

Rokkan, Aksel \& Bovik, Arnt. Inter-Firm Cooperation and the Problem of Free Riding Behavior: An Empirical Study of Voluntary Retail Chains. Journal of Purchasing and Supply Management 9(2003):5-6, pp. 247-256.

Rosenkopf, Lori. Comparing Alliance Network Structure Across Industries: Observations and Explanations. Strategic Entrepreneurship Journal 1(2007):3-4, pp. 191-209.

Routledge, Paul; Nativel, Corinne \& Cumbers, Andrew. Entangled Logics and Grassroots Imaginaries of Global Justice Networks. Environmental Politics 15(2006):5, pp. 839-859.
Traxler, Franz; Brandl, Bernd; Glassner, Vera \& Ludwig, Alice. Can Cross-Border Bargaining Coordination Work? Analytical Reflections on its Feasibility and Evidence From Germany's and Austria's Metal Industry. European Journal of Industrial Relations 14(2008):2, pp. 217-237.

Vegso, Raymond. Cooperation, Coordination, and Collaboration in Organizations. Canisius College School of Business Administration Press, Buffalo 1986.

Walker, Gordon; Kogut, Bruce \& Shan,Weijian. Social Capital, Structural Holes and the Formation of an Industry Network. Organization Science 8(1997):2, pp. 109-125.

Wittek, Rafael \& Van de Bunt, Gerhard. Organizational Governance, Informal Networks and Oppositional Solidarity in Organizations. Paper presented at the annual meeting of the American Sociological Association in Atlanta 2003.

Wright, Maurice. Policy Community, Policy Network and Comparative Industrial Policies. Political Studies 36(1988):2, pp. 593-612. 